\title{
Investigation of Lymphocyte Subsets in Peripheral Blood of Patients with Dyslipidemia
}

\section{Da-Ming $\mathrm{Xu},{ }^{1, *}$ Qian $\mathrm{Li}^{2, *}$ Jing-Xing $\mathrm{Yi}^{3}{ }^{3}, *$ Xin-Jian Cai, ${ }^{3}$ Long Xie, ${ }^{3}$ Wei Fang, ${ }^{3}$ Jin- Feng Qiu, ${ }^{4}$ Cheng-Wei $X u,{ }^{5}$ Chun-Ling $\mathrm{He},{ }^{6}$ Xian-Ru Xu, ${ }^{7}$ Jie-Song $X u^{8}$ Jun $Y$ in $\mathbb{D}^{2,3}$}

'Division of Urological Surgery, Second Affiliated Hospital of Shantou University Medical College, Shantou, Guangdong, People's Republic of China; ${ }^{2}$ Division of Hematology, Second Affiliated Hospital of Shantou University Medical College,

Shantou, Guangdong, People's Republic of China; ${ }^{3}$ Department of Clinical

Laboratory Medicine, Second Affiliated Hospital of Shantou University Medical College, Shantou, Guangdong, People's Republic of China; ${ }^{4}$ Division of Respirology, Second Affiliated Hospital of Shantou University Medical College, Shantou, Guangdong, People's Republic of China; ${ }^{5}$ Department of Blood

Purification, Second Affiliated Hospital of Shantou University Medical College,

Shantou, Guangdong, People's Republic of China; ${ }^{6}$ Department of Pathology, Second Affiliated Hospital of Shantou University Medical College, Shantou, Guangdong, People's Republic of China; ${ }^{7}$ Division of Interventional Ultrasonic Therapeutics, Second Affiliated Hospital of Shantou University Medical College, Shantou, Guangdong, People's Republic of China; ${ }^{8}$ Department of Electroencephalogram, Second Affiliated Hospital of Shantou University Medical College, Shantou, Guangdong, People's Republic of China

*These authors contributed equally to this work

Correspondence: Jun Yin Department of Clinical Laboratory Medicine and Division of Hematology, Second Affiliated Hospital of Shantou University Medical College, Dongxia Road North, Shantou, Guangdong Province, 5I504I, People's Republic of China Tel +867548891 5950

Email jyin@stu.edu.cn
Objective: In order to evaluate the effect of dyslipidemia on cellular or humoral immunity in patients, changes in the absolute number of lymphocyte subsets were detected.

Methods: Flow cytometry was applied to determine the absolute value of lymphocyte subsets: $\mathrm{B}$ cell, $\mathrm{NK}$ cell, $\mathrm{CD} 4^{+} \mathrm{T}$ cell including the functional subset $\left(\mathrm{CD} 4^{+} \mathrm{CD} 28^{+}\right)$, native subset $\left(\mathrm{CD}^{+}{ }^{+} \mathrm{CD} 45 \mathrm{RA}^{+} \mathrm{CD}^{2} \mathrm{~L}^{+}\right)$, memory $\mathrm{T}$ cell subset $\left(\mathrm{CD} 4^{+} \mathrm{CD} 45 \mathrm{RA}^{-}\right), \mathrm{CD}^{+} \mathrm{T}$ cell including the functional subset $\left(\mathrm{CD}^{+} \mathrm{CD} 28^{+}\right)$and activated subsets $\left(\mathrm{CD} 8^{+} \mathrm{CD} 38^{+}\right.$and $\mathrm{CD}^{+} \mathrm{DR}^{+}$). The relationship between lymphocyte subsets and hypercholesterolemia and hypertriglyceridemia was analyzed.

Results: The absolute values of $\mathrm{CD} 19^{+} \mathrm{B}$ cell, $\mathrm{CD} 3^{+} \mathrm{T}$ cell, $\mathrm{CD} 4^{+}$Th cell, $\mathrm{CD} 4^{+} \mathrm{CD} 28^{+}$cell, naive $\mathrm{CD}^{+}{ }^{+} \mathrm{T}$ cell and memory $\mathrm{CD}^{+} \mathrm{T}$ cell in patients with dyslipidemia were markedly higher than those in healthy controls $(P<0.05)$. There was no significant difference between healthy controls and dyslipidemia patients in other lymphocyte subsets $(P>0.05)$. The absolute values of $\mathrm{CD}^{+} \mathrm{T}$ cell and naive $\mathrm{CD}^{+} \mathrm{T}$ cell were significantly positively correlated with hypercholesterolemia in peripheral blood ( $\mathrm{r}=0.291$ and 0.306 , respectively, all $P<0.05$ ). There was no significant correlation between hypertriglyceridemia and lymphocyte subsets $(P>0.05)$.

Conclusion: Dyslipidemia has potential effects on immune profiles in lymphocytes subsets, and changes in lymphocyte subsets in dyslipidemia patients may lead to immune dysfunction.

Keywords: dyslipidemia, lymphocyte subsets, flow cytometry

\section{Introduction}

Dyslipidemia, which comes with high levels of total cholesterol (TC), triglycerides (TG) and low-density lipoprotein (LDL) or low levels of high-density lipoprotein (HDL) in plasma for clinical feature, is a risk factor for atherosclerotic cardiovascular disease, cerebrovascular accident, peripheral arterial disease and type 2 diabetes. ${ }^{1,2}$ However, the pathogenesis of other diseases caused by dyslipidemia is complex and has not been fully elucidated so far. To overcome this gap, more and more researchers have studied the interaction between dyslipidemia and immunity. Studies on the mechanism of dyslipidemia related to cardiovascular diseases or immunity disorder have found that lipoprotein metabolism plays an important role in the development of coronary atherosclerosis and the activation of white blood cells, whereas the lowering of lipid interventions has been good for immunomodulatory and anti-inflammatory clinical studies. ${ }^{3,4}$ Evidence from clinical data and mechanism study suggested that hypercholesterolemia may induce an interaction between mast cell and $\mathrm{CD} 4{ }^{+} \mathrm{T}$ cell in coronary atherosclerosis. ${ }^{5} \mathrm{In}$ addition, dyslipidemia induced an increase in the number of both neutrophil granulocyte and mononuclear leucocyte in animal models and clinical trials. ${ }^{6}$ Moreover, an 
increased number of both types of cells have been shown to correlate with plaque load in cardiovascular regions. ${ }^{7}$

Lymphocytes, produced by lymphatic organs, are a significant part of the Immunity function and the main performer of immune function. They are responsible for fighting external infection and monitoring cell variation, which can be divided into T lymphocytes, B lymphocytes and NK cells, and mature T cells can be divided into $\mathrm{CD}^{+} \mathrm{CD}^{+}$cells and $\mathrm{CD}^{+} \mathrm{CD}^{+}$ cells. According to the different surface molecular markers and functions, $\mathrm{CD}^{+}$and $\mathrm{CD} 8^{+} \mathrm{T}$ lymphocytes can be further divided into functional subsets $\left(\mathrm{CD} 4^{+} / \mathrm{CD} 8^{+} \mathrm{CD} 28^{+}\right)$, activation subsets $\left(\mathrm{CD}^{+} / \mathrm{CD} 8^{+} \mathrm{CD} 38^{+}\right)$, innocence subsets $\left(\mathrm{CD}^{+}{ }^{+} \mathrm{CD} 45 \mathrm{RA}^{+} \mathrm{CD} 62 \mathrm{~L}^{+}\right)$and memory subsets $\left(\mathrm{CD}^{+} \mathrm{CD}^{+} 5 \mathrm{RA}^{-}\right)$. $\mathrm{CD}^{+} \mathrm{T}$ lymphocytes can assist the development and differentiation of other lymphocytes and secrete a large number of cytokines to regulate cellular immunity and humoral immunity. $\mathrm{CD}^{+} \mathrm{T}$ lymphocytes have inhibitory and lethal effects, among which $\mathrm{CD} 8^{+}$inhibitory $\mathrm{T}$ cells have the function of inhibiting humoral immunity and cellular immunity. B lymphocytes play an immunomodulatory role in humoral immunity mainly by producing antibodies. Natural killer (NK) cells participate in natural immunity and have the role of killing target cells. Peripheral blood lymphocyte subsets are important indicators to evaluate the immune function. In a recent study, $\mathrm{CD} 4^{+} \mathrm{T}$ cells subsets were found to be differentially expressed in patients with atherosclerosis. ${ }^{8}$ Moreover, differential peripheral white blood cell counts may indicate the risk of dyslipidemia. ${ }^{9}$ Some studies have also found that neutrophil subsets are expressed differently in patients with dyslipidemia. ${ }^{10}$ Several studies have suggested that dyslipidemia is related to inflammation and immune disorder, but studies on the relationship between dyslipidemia and lymphocyte subsets are still lacking. ${ }^{11,12}$ In order to explore the influence of dyslipidemia on immune function, the absolute level of peripheral blood lymphocyte subsets in patients with dyslipidemia was detected, and the correlation between peripheral blood lymphocyte subsets and hypercholesterolemia and hypertriglyceridemia was analyzed in this study, which aim to provide a new idea for clinical diagnosis, therapy and prevention of dyslipidemia.

\section{Materials and Methods}

\section{Patient Enrollment and Blood Specimen Collection}

Under the diagnostic standard of dyslipidemia from "The 2017 guidelines for prevention and treatment of dyslipidemia in Chinese adults", 51 adult patients with 32 male and
19 female diagnosed as having dyslipidemia, which manifested without any other physical disorders that may lead dyslipidemia, as well as 51 adult healthy volunteers (control) with 32 male and 19 female, whose presented normal blood lipids and no concurrent diseases or drug therapy at the moment of blood drawing, were selected into our research. The healthy people were matched with dyslipidemia patients of similar ages and genders. $10 \mathrm{~mL}$ whole blood sample from each subject was allowed to collect into a tube with heparin. The blood samples were stored at ambient temperature and moved within 2 hours from the clinical wards to the analytical laboratory, where they were immediately processed.

Criteria for determining dyslipidemia: "The 2017 guidelines for prevention and treatment of dyslipidemia in Chinese adults": One or more abnormalities in $\mathrm{TC} \geq 6.22 \mathrm{mmol} / \mathrm{L}, \mathrm{TG} \geq$ $2.3 \mathrm{mmol} / \mathrm{L}$, and $\mathrm{LDL} \geq 4.14 \mathrm{mmol} / \mathrm{L}$ were defined as dyslipidemia. The reference range of dyslipidemia in the biochemical room of our hospital was $\mathrm{TC} \geq 5.71 \mathrm{mmol} / \mathrm{L}, \mathrm{TG} \geq 1.70 \mathrm{mmol} /$ $\mathrm{L}$, and $\mathrm{LDL} \geq 3.12 \mathrm{mmol} / \mathrm{L}$, respectively. Exclusion criteria: (1) patients with various acute and chronic infections; (2) Patients with diabetes and complications; (3) Patients with diseases of the blood system; (4) Patients with autoimmune diseases; (5) Patients using hormones; (6) Patients with hyperuricemia; (7) Patients with malignant tumor; (8) Patients with coronary heart disease; (9) Patients with hypertension; (10) Patients with endocrine-related diseases, such as thyroid dysfunction.

\section{Detection of Lymphocyte Subsets in Peripheral Blood}

One BD Trucount absolute counter tube was selected and labeled as No. 1 tube, and two tubes for flow cytometry were labeled as No. 2 and No. 3 tubes, respectively. $20 \mathrm{ul}$ of Multitest $^{\mathrm{TM}}$ 6-Color TBNK Reagent and $50 \mathrm{ul}$ of heparin anticoagulant peripheral blood were allowed to be added into the No.1 tube. After mixing evenly, it was incubated for 20 mins in dark at room temperature. Afterward, 450 ul diluted Red Blood Cell Lysis Buffer was added into the absolute counter tube, mixed evenly and kept in the dark at room temperature for $20 \mathrm{mins}$, and then the flow cytometer (Becton Dickinson) was applied to detect and analyze the lymphocyte subsets. 20 ul fluorescent antibodies HLA-DRFITC, CD28-PE, CD4-PerCP-Cy5.5, CD8-PE-Cy7, CD38APC, and CD3-APC-Cy7 were, respectively, added into No. 2 tube. In addition, $20 \mathrm{ul}$ of fluorescent antibodies CD45RAFITC, CD62L-PE, CD4-PerCP-Cy5.5 were, respectively, added into No. 3 tube. 50 ul heparin anticoagulant peripheral 
blood was added into the No.2 and No.3 tubes, respectively, and then, the tubes were mixed by eddy oscillation and incubated for 20 mins in the dark at room temperature. $2 \mathrm{~mL}$ hemolysin was added, and tubes were incubated for 20 mins in the dark at room temperature, followed by centrifugation at $500 \mathrm{~g}$ for 5 mins. After completion of centrifugation, the supernatant was poured out and the precipitation was left. 1 $\mathrm{mL}$ PBS buffer was added to resuspend the cell, and then, the cell was mixed by vortex and ready to be tested.

\section{Statistical Analysis}

Data are expressed as mean $\pm \mathrm{SD}$. A Student's $t$-test was used to determine the difference between the two groups. An $X^{2}$ test was used for comparison of enumeration data. Statistical analyses were performed by using the Statistical Program for Social Sciences (SPSS) 20.0 software (SPSS Inc. Chicago, IL, USA). A $P$-value $<0.05$ was considered statistically significant. The two groups of data conformed to the normal distribution and the correlation analysis was performed by Pearson test.

\section{Results}

\section{Basic Information of Peripheral Blood in Two Groups}

The level of TC, TG and LDL in dyslipidemia patients was significantly higher than those in healthy controls $(P<0.05)$. In addition, there were no markedly differences in age, gender, fasting plasma glucose (FPG) and uric acid (UA) between healthy controls and dyslipidemia patients $(P>0.05)$ (Table 1).

\section{The Absolute Value of Lymphocyte Subsets in Peripheral Blood of Each Group}

The absolute values of $\mathrm{CD} 19^{+} \mathrm{B}$ cell, $\mathrm{CD}^{+} \mathrm{T}^{-}$cell, $\mathrm{CD} 4^{+}$ Th cell, $\mathrm{CD} 4^{+} \mathrm{CD} 28^{+}$cell, naive $\mathrm{CD} 4^{+} \mathrm{T}$ cell and memory $\mathrm{CD}^{+} \mathrm{T}$ cell in patients with dyslipidemia were significantly higher than those in healthy controls $(P<0.05)$. There was no significant difference between healthy controls and dyslipidemia patients in other lymphocyte subsets $(P>0.05)$ (Table 2 and Figures 1 and 2 ).

\section{Correlation Analysis of Lymphocyte Subsets with Total Cholesterol and Triacylglycerol in Dyslipidemia Patients}

The absolute values of $\mathrm{CD}^{+}{ }^{+} \mathrm{T}$ cell and naive $\mathrm{CD}^{+} \mathrm{T}$ cell were markedly positively correlated with hypercholesterolemia in peripheral blood $(\mathrm{r}=0.291$ and 0.306 , respectively, all $P<0.05)$. There was no significant correlation between hypertriglyceridemia and lymphocyte subsets $(P>0.05)$ (Table 3).

\section{Discussion}

Clinical and Laboratory researchers have suggested that lipid metabolism acts as a pivotal part of immunity, which may have significant implications for cardiovascular disease, infectious disease, autoimmune disease and metabolic dysfunction. ${ }^{4,13-15}$ In our study of 51 dyslipidemia patients and healthy controls who underwent physical examination in our hospital from January 2020 to October 2020, we have demonstrated that some lymphocyte subsets were significantly overexpressed in patients and there are significant relationships between $\mathrm{CD}^{+} /$naive $\mathrm{CD}^{+} \mathrm{T}$ cell and hypercholesterolemia in peripheral blood. Our research found that dyslipidemia may have potential effects on immunity in both humoral and cellular immunity, whereas hypertriglyceridemia seems to have little correlation with lymphocyte subsets. Further, hypercholesterolemia majorly affects immune profiles in cellular immunity, leading to variable immune outcomes. Studies have shown that lipoprotein can directly affect the structure and activity of monocyte by regulating cholesterin flux of cell, modulating lipid rafts tissue, isolating pathogenic stimulus and providing immunoregulatory effect. ${ }^{4,16}$ Lymphocyte and monocyte are both a kind of leukocyte, but there are a limited number of reports about lipoprotein and lymphocyte subsets. As a matter of fact, our research

Table I Comparison of Peripheral Blood Features Between Healthy Controls and Dyslipidemia Patients in Peripheral Blood

\begin{tabular}{|l|c|c|c|c|c|c|c|}
\hline Groups & $\begin{array}{c}\text { Gender } \\
\text { (Male/Female) }\end{array}$ & Age & $\begin{array}{c}\text { TC } \\
\mathbf{( m m o l / L )}\end{array}$ & $\begin{array}{c}\text { TG } \\
(\mathbf{m m o l} / \mathbf{L})\end{array}$ & $\begin{array}{c}\text { LDL } \\
(\mathbf{m m o l} / \mathbf{L})\end{array}$ & $\begin{array}{c}\text { UA } \\
(\mathbf{u m o l} / \mathbf{L})\end{array}$ & $\begin{array}{c}\text { FPG } \\
(\mathbf{m m o l} / \mathbf{L})\end{array}$ \\
\hline Healthy controls & $5 \mathrm{I}(32 / 19)$ & $46 \pm 13$ & $4.47 \pm 0.47$ & $1.03 \pm 0.29$ & $2.75 \pm 0.32$ & $333 \pm 49$ & $5.1 \pm 0.31$ \\
Dyslipidemia & $5 \mathrm{I}(32 / 19)$ & $48 \pm 12$ & $6.36 \pm 0.91^{*}$ & $2.68 \pm 2.29 *$ & $4.05 \pm 0.63 *$ & $364 \pm 0.48$ & $5.0 \pm 0.45$ \\
patients & & & & & & \\
\hline
\end{tabular}

Note: *Comparison with the group of healthy controls $(P<0.05)$.

Abbreviations: TC, total cholesterol; TG, triglycerides; LDL, low-density lipoprotein; UA, uric acid; FPG, fasting plasma glucose. 
Table 2 Comparison of Lymphocyte Subsets Between Healthy Controls and Dyslipidemia Patients in Peripheral Blood (Cells/uL)

\begin{tabular}{|l|l|l|}
\hline Lymphocyte Subsets & $\begin{array}{l}\text { Healthy } \\
\text { Controls (N=5 I) }\end{array}$ & $\begin{array}{l}\text { Dyslipidemia } \\
\text { Patients (N=5 I) }\end{array}$ \\
\hline $\mathrm{CD} 3^{+} \mathrm{T}$ cell & $1541.6 \pm 356.9$ & $2052.5 \pm 607.0^{*}$ \\
$\mathrm{CD} 4^{+}$Th cell & $720.1 \pm 176.2$ & $1136.0 \pm 365.4^{*}$ \\
$\mathrm{CD} 8^{+} \mathrm{Tc}$ cell & $670.8 \pm 195.1$ & $791.8 \pm 294.2$ \\
$\mathrm{CD} 4 / \mathrm{CD} 8$ & $1.15 \pm 0.33$ & $1.54 \pm 0.46^{*}$ \\
$\mathrm{CD} 19^{+} \mathrm{B}$ cell & $249.9 \pm 65.3$ & $346.6 \pm 140.7^{*}$ \\
$\mathrm{CD} 3^{-} \mathrm{CD} 16^{+} \mathrm{CD} 56^{+} \mathrm{NK}$ cell & $514.8 \pm 284.4$ & $665.5 \pm 323.5$ \\
$\mathrm{CD} 4^{+} \mathrm{CD} 28^{+}$cell & $668.7 \pm 155.1$ & $1022.5 \pm 351.5^{*}$ \\
$\mathrm{Naiv}^{\mathrm{CD}} 4^{+} \mathrm{T}$ cell & $175.7 \pm 83.7$ & $352.0 \pm 149.9^{*}$ \\
${\mathrm{Memory} C D 4^{+}}^{+}$cell & $489.3 \pm 159.9$ & $677.2 \pm 243.4^{*}$ \\
$\mathrm{CD} 8^{+} \mathrm{CD} 28^{+}$cell & $348.1 \pm 108.2$ & $444.9 \pm 242.8$ \\
$\mathrm{CD} 8^{+} \mathrm{CD} 38^{+}$cell & $143.2 \pm 38.2$ & $147.0 \pm 101.3$ \\
$\mathrm{CD} 8^{+} \mathrm{CDDR}{ }^{+}$cell & $229.5 \pm 139.5$ & $245.5 \pm 155.0$ \\
\hline
\end{tabular}

Note: *Comparison with the group of healthy controls $(P<0.05)$.

is the first to uncover the interaction between lymphocyte subsets and dyslipidemia.

The relationship between lymphocyte subsets and lipids, as well as the excitatory or inhibitory regulation in these lymphocyte cells have been the research hotspots of cardiovascular disorders in recent research. In our study, the level of $\mathrm{CD} 19^{+} \mathrm{B}$ cell, $\mathrm{CD}^{+} \mathrm{T}$ cell, $\mathrm{CD}^{+} \mathrm{Th}$ cell, $\mathrm{CD} 4^{+} \mathrm{CD} 28^{+}$cell, naive $\mathrm{CD} 4^{+} \mathrm{T}$ cell and memory $\mathrm{CD} 4^{+} \mathrm{T}$ cell were in a state of markedly increased expression in patients diagnosed as having dyslipidemia compared to healthy controls. B cells have three main effects: the production of antibody, the presentation of antigen or $\mathrm{T}$ cell interaction, and the release of cell factor. It was reported that all of the effect can regulate atherosclerosis and were associated with the activation status of the B cells, ${ }^{17}$ which was consistent with the enhanced expression of B cells in patients with dyslipidemia observed in our experiment. Other experimental data indicated that changes in cellular lipid metabolism may have critical effects on humoral and cellular immunity, especially $\mathrm{T}$ cells and $\mathrm{T}$ cell subsets proliferation and cell fate decisions. Most adaptive immune responses require the activation of specific $\mathrm{T}$ cells via the $\mathrm{T}$ cell antigen receptor-CD3 complex. Researchers used a natural analogue of cholesterol that inhibited the phosphorylation reaction of CD3 ITAM, leading to a decrease in the activation of T cell. ${ }^{18}$ Bagley et al found that hyperlipidemia promoted expedited repulsion of vascularized heart allografts in mouse by the inductive effect of anti-donor $\mathrm{CD}^{+}{ }^{+} \mathrm{Th}$ cells and hyperlipidemia also promoted an increase in effector T cells. ${ }^{19}$ These studies suggested that lipid metabolism may also play a critical role in activation-induced proliferation and differentiation of $\mathrm{T}$ lymphocyte. Together, we speculate that Lipid is not only a structural molecule required for cell membrane formation and proliferation but also a central switch regulating $T$ cell fate determination. In addition,

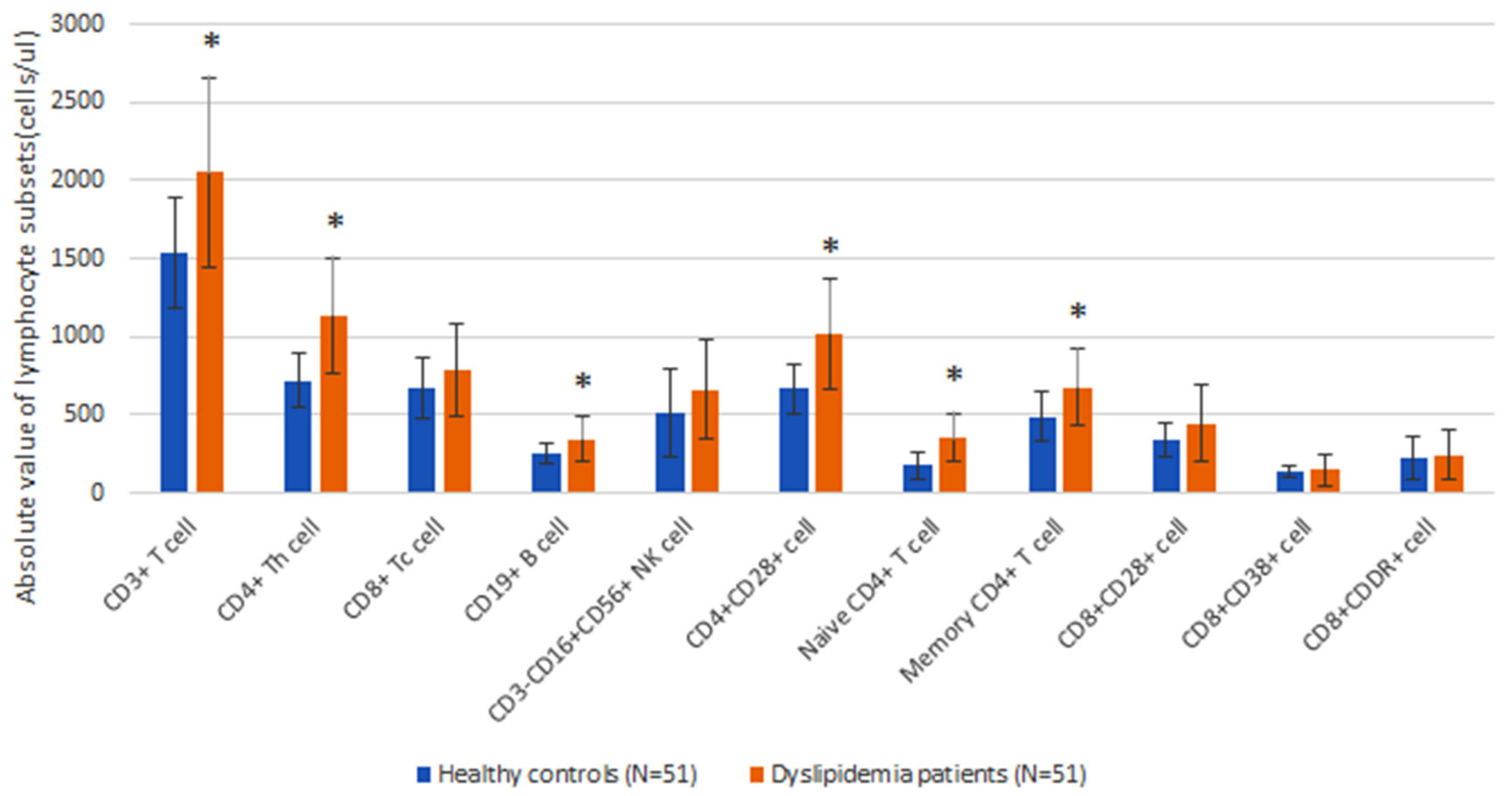

Figure I Comparison of lymphocyte subsets between healthy controls and dyslipidemia patients. *Comparison with the group of healthy controls $(P<0.05)$. 


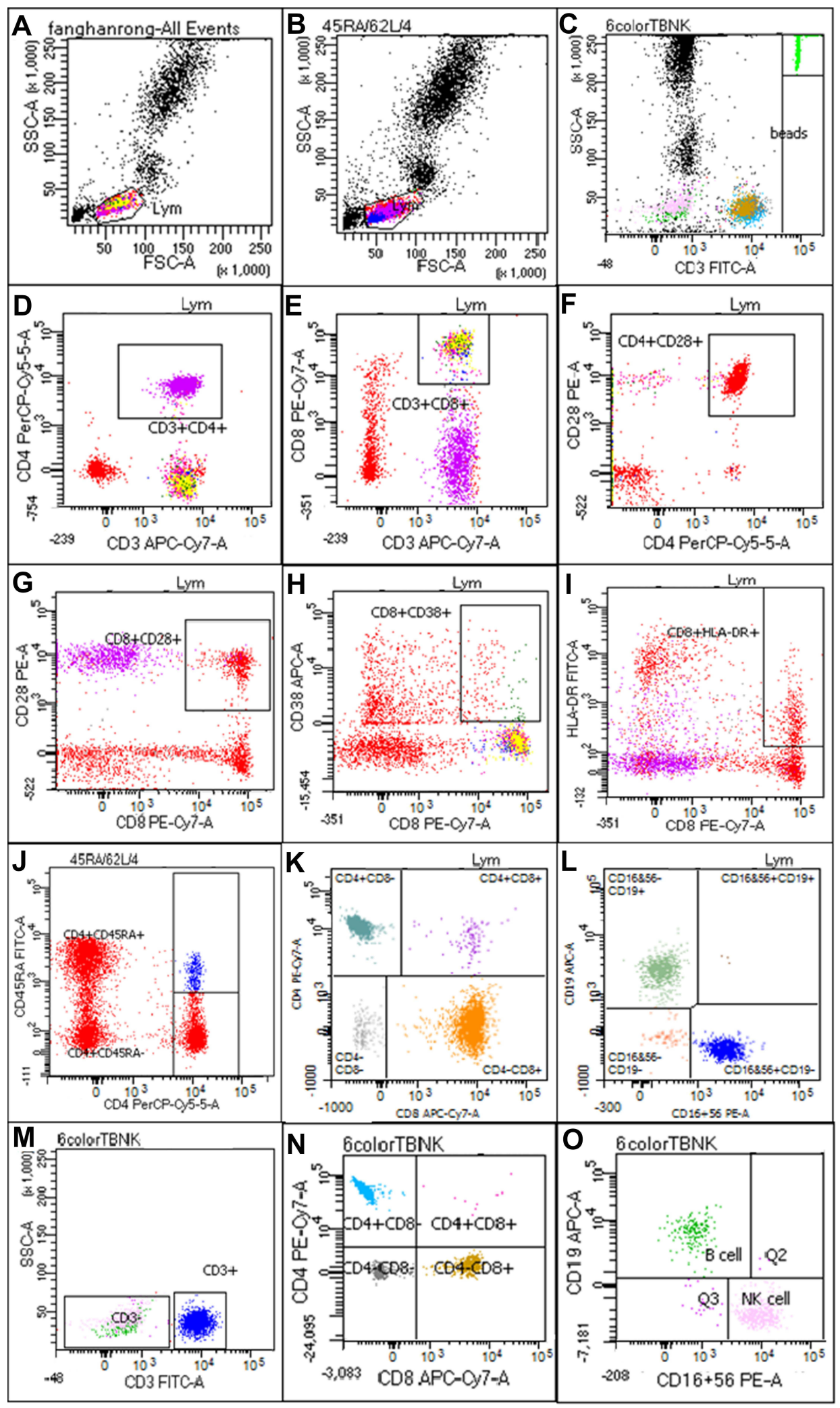

Figure 2 Flow cytometry of lymphocyte subsets $(\mathbf{A}-\mathbf{O})$. T lymphocytes $\left(\mathrm{CD} 3^{+}\right)$, B lymphocytes $\left(\mathrm{CDI} 19^{+}\right)$, Natural killer $(\mathrm{NK})$ lymphocytes $\left(\mathrm{CD} 3^{-} \mathrm{CDI} 6^{+}\right.$and/or $\left.\mathrm{CD} 56^{+}\right)$, Helper inducer $T$ lymphocytes $\left(\mathrm{CD}^{+} \mathrm{CD}^{+}\right)$, Functional subset of $\mathrm{CD} 4^{+} \mathrm{T}$ cell $\left(\mathrm{CD} 4^{+} \mathrm{CD} 28^{+}\right)$, Native subset of $\mathrm{CD} 4^{+} \mathrm{T}$ cell $\left(\mathrm{CD} 4^{+} \mathrm{CD} 45 \mathrm{RA} \mathrm{A}^{+} \mathrm{CD} 62 \mathrm{~L}^{+}\right)$, memory $\mathrm{T}$ cell subset $\left(C D 4^{+} C D 45 R A^{-}\right)$, Suppressor cytotoxic $T$ lymphocytes $\left(C D 3^{+} C D 8^{+}\right)$, Functional subset of $C D 8^{+} \mathrm{T}$ cell $\left(\mathrm{CD} 8^{+} \mathrm{CD} 28^{+}\right)$, Activated subsets of $\mathrm{CD} 8^{+} \mathrm{T}$ cell $\left.\left(\mathrm{CD} 8^{+} \mathrm{CD} 38^{+} \text {and } \mathrm{CD} 8^{+} \mathrm{DR}\right)^{+}\right)$. 
Table 3 Correlation Analysis of Lymphocyte Subsets with Hypercholesterolemia and Hypertriglyceridemia in Dyslipidemia Patients

\begin{tabular}{|c|c|c|c|c|}
\hline \multirow[t]{2}{*}{ Lymphocyte Subsets } & \multicolumn{2}{|c|}{ Hypercholesterolemia } & \multicolumn{2}{|c|}{ Hypertriglyceridemia } \\
\hline & r Value & $P$ value & r Value & $P$ value \\
\hline Gender & 0.025 & 0.864 & -0.143 & 0.317 \\
\hline Age & 0.050 & 0.727 & -0.147 & 0.305 \\
\hline $\mathrm{CD}^{+} \mathrm{T}$ cell & 0.291 & 0.038 & 0.070 & 0.625 \\
\hline $\mathrm{CD}^{+}{ }^{+}$Th cell & 0.265 & 0.060 & 0.015 & 0.918 \\
\hline $\mathrm{CD}^{+} \mathrm{Tc}^{\mathrm{T}}$ cell & 0.206 & 0.148 & 0.054 & 0.704 \\
\hline $\mathrm{CD} 4 / \mathrm{CD} 8$ & 0.037 & 0.796 & -0.065 & 0.649 \\
\hline $\mathrm{CD} / 9^{+} \mathrm{B}$ cell & -0.060 & 0.675 & -0.021 & 0.885 \\
\hline $\mathrm{CD}^{-} \mathrm{CD} 16^{+} \mathrm{CD} 56^{+} \mathrm{NK}$ cell & 0.086 & 0.546 & 0.099 & 0.490 \\
\hline $\mathrm{CD}^{+} \mathrm{CD} 28^{+}$cell & 0.191 & 0.179 & 0.057 & 0.691 \\
\hline Naive $\mathrm{CD}^{+} \mathrm{T}$ cell & 0.306 & 0.029 & 0.017 & 0.906 \\
\hline Memory $\mathrm{CD}^{+} \mathrm{T}$ cell & 0.185 & 0.194 & 0.033 & 0.816 \\
\hline
\end{tabular}

dyslipidemia profoundly affects $\mathrm{T}$ cell subsets and alterations in $T$ cell subsets may also seem to cause the change in immune effect. Therefore, lipid-lowering therapy may be a potential treatment path for autoimmune diseases or immune rejection.

Based on a further study of the relationships between dyslipidemia and lymphocyte subsets, we found that $\mathrm{CD}^{+}$ $\mathrm{T}$ cell and naive $\mathrm{CD}^{+} \mathrm{T}$ cell were markedly positively associated with hypercholesterolemia in peripheral blood. Mailer et al suggested that hypercholesterolemia enhanced $\mathrm{T}$ cell antigen receptor stimulation and $\mathrm{T}$ cell development, as well as T cell proliferation. ${ }^{20}$ However, Maganto-García et al found that prolonged hypercholesterolemia can impair $\mathrm{T}$ cell but not the accumulation of lymphocyte, and the lipid-lowering can prevent the decrease of $\mathrm{T}$ lymphocyte in lesion. ${ }^{21}$ Additionally, Baardman et al suggested that the low level of $\mathrm{T}$ cells and Impaired inhibition effect were related to the progress of atherosclerosis. $^{22}$ Together, atherosclerosis is a chronic inflammatory disease of the arterial wall and a major cause of cardiovascular disease. Its progression is closely related to the number and function of lymphocyte subsets, especially $\mathrm{T}$ cell subsets. Therefore, we speculate that therapeutic strategy to improve the level or function of $\mathrm{T}$ lymphocyte could be beneficial to preventing the development of dyslipidemia-related diseases.

\section{Conclusion}

In summary, dyslipidemia has potential effects on immune profiles in lymphocytes subsets, and changes in the absolute number of lymphocyte subsets in dyslipidemia patients may lead to immune dysfunction.

\section{Ethics Approval}

The study protocols were conducted according to the principles of the Declaration of Helsinki and were approved by the Scientific and Medical Ethical Committee of the Second Affiliated Hospital of Shantou University Medical College. All the subjects gave their written informed consent before their inclusion in the study.

\section{Author Contributions}

All authors made substantial contributions to conception and design, acquisition of data, or analysis and interpretation of data; took part in drafting the article or revising it critically for important intellectual content; agreed to submit to the current journal; gave final approval for the version to be published; and agreed to be accountable for all aspects of the work.

\section{Funding}

There is no funding to report.

\section{Disclosure}

Da-Ming $\mathrm{Xu}$, Qian Li, and Jing-Xing Yi are co-first authors for this study. The authors declare that they have no competing interests.

\section{References}

1. Kopin L, Lowenstein C. Dyslipidemia. Ann Intern Med. 2017;167(11): ITC81-ITC96. doi:10.7326/AITC201712050

2. Mooradian AD. Dyslipidemia in type 2 diabetes mellitus. Nat Clin Pract Endocrinol Metab. 2009;5(3):150-159. doi:10.1038/ncpendmet1066

3. Yoon SS, Dillon CF, Carroll M, Illoh K, Ostchega Y. Effects of statins on serum inflammatory markers: the U.S. national health and nutrition examination survey 1999-2004. J Atheroscler Thromb. 2010;17 (11):1176-1182. doi: $10.5551 /$ jat.5652 
4. Andersen CJ. Impact of dietary cholesterol on the pathophysiology of infectious and autoimmune disease. Nutrients. 2018;10(6):764. doi:10.3390/nu10060764

5. Kritikou E, van der Heijden T, Swart M, et al. Hypercholesterolemia induces a mast cell-CD4+ $\mathrm{T}$ cell interaction in atherosclerosis. $J$ Immunol. 2019;202(5):1531-1539. doi:10.4049/jimmunol.1800648

6. Giugliano G, Brevetti G, Lanero S, Schiano V, Laurenzano E, Chiariello M. Leukocyte count in peripheral arterial disease: a simple, reliable, inexpensive approach to cardiovascular risk prediction. Atherosclerosis. 2010;210(1):288-293. doi:10.1016/j.atheroscle rosis.2009.11.009

7. Drechsler M, Megens RT, van Zandvoort M, Weber C, Soehnlein O. Hyperlipidemia-triggered neutrophilia promotes early atherosclerosis. Circulation. 2010;122(18):1837-1845. doi:10.1161/CIRCULATI ONAHA.110.961714

8. Tay MHD, Lim SYJ, Leong YFI, et al. Halted lymphocyte egress via efferent lymph contributes to lymph node hypertrophy during hypercholesterolemia. Front Immunol. 2019;10:575. doi:10.3389/ fimmu.2019.00575

9. Corbi SCT, de Vasconcellos JF, Bastos AS, et al. Circulating lymphocytes and monocytes transcriptomic analysis of patients with type 2 diabetes mellitus, dyslipidemia and periodontitis. Sci Rep. 2020;10 (1):8145. doi:10.1038/s41598-020-65042-9

10. Guasti L, Maresca AM, Schembri L, et al. Relationship between regulatory $\mathrm{T}$ cells subsets and lipid profile in dyslipidemic patients: a longitudinal study during atorvastatin treatment. BMC Cardiovasc Disord. 2016;16:26. doi:10.1186/s12872-016-0201-y

11. Liu Y, Kong X, Wang W, et al. Association of peripheral differential leukocyte counts with dyslipidemia risk in Chinese patients with hypertension: insight from the China stroke primary prevention trial. J Lipid Res. 2017;58(1):256-266. doi:10.1194/jlr.P067686

12. Genkel V, Dolgushin I, Baturina I, et al. Associations between hypertriglyceridemia and circulating neutrophil subpopulation in patients with dyslipidemia. Int J Inflam. 2021;2021:6695468. doi:10.1155/ 2021/6695468
13. Andersen CJ, Murphy KE, Fernandez ML. Impact of obesity and metabolic syndrome on immunity. Adv Nutr. 2016;7(1):66-75. doi:10.3945/an.115.010207

14. Pirillo A, Catapano AL, Norata GD. HDL in infectious diseases and sepsis. Handb Exp Pharmacol. 2015;224:483-508. doi:10.1007/9783-319-09665-0_15

15. Andersen CJ, Lee JY, Blesso CN, Carr TP, Fernandez ML. Egg intake during carbohydrate restriction alters peripheral blood mononuclear cell inflammation and cholesterol homeostasis in metabolic syndrome. Nutrients. 2014;6(7):2650-2667. doi:10.3390/nu6072650

16. Thompson PA, Kitchens RL. Native high-density lipoprotein augments monocyte responses to lipopolysaccharide (LPS) by suppressing the inhibitory activity of LPS-binding protein. J Immunol. 2006;177(7):4880-4887. doi:10.4049/jimmunol.177.7.4880

17. Ma SD, Mussbacher M, Galkina EV. Functional role of B cells in atherosclerosis. Cells. 2021;10(2):270. doi:10.3390/cells10020270

18. Wang F, Beck-García K, Zorzin C, Schamel WW, Davis MM. Inhibition of $\mathrm{T}$ cell receptor signaling by cholesterol sulfate, a naturally occurring derivative of membrane cholesterol. Nat Immunol. 2016;17(7):844-850. doi:10.1038/ni.3462

19. Bagley J, Yuan J, Chandrakar A, Iacomini J. Hyperlipidemia alters regulatory $\mathrm{T}$ cell function and promotes resistance to tolerance induction through costimulatory molecule blockade. Am J Transplant. 2015;15(9):2324-2335. doi:10.1111/ajt.13351

20. Mailer RKW, Gisterå A, Polyzos KA, Ketelhuth DFJ, Hansson GK. Hypercholesterolemia enhances $\mathrm{T}$ cell receptor signaling and increases the regulatory $\mathrm{T}$ cell population. Sci Rep. 2017;7 (1):15655. doi:10.1038/s41598-017-15546-8

21. Maganto-García E, Tarrio ML, Grabie N, Bu DX, Lichtman AH. Dynamic changes in regulatory $\mathrm{T}$ cells are linked to levels of dietinduced hypercholesterolemia. Circulation. 2011;124(2):185-195. doi:10.1161/CIRCULATIONAHA.110.006411

22. Baardman J, Lutgens E. Regulatory $\mathrm{T}$ cell metabolism in atherosclerosis. Metabolites. 2020;10(7):279. doi:10.3390/metabo10070279
International Journal of General Medicine

\section{Publish your work in this journal}

The International Journal of General Medicine is an international, peer-reviewed open-access journal that focuses on general and internal medicine, pathogenesis, epidemiology, diagnosis, monitoring and treatment protocols. The journal is characterized by the rapid reporting of reviews, original research and clinical studies across all disease areas. The manuscript management system is completely online and includes a very quick and fair peer-review system, which is all easy to use. Visit http://www.dovepress.com/ testimonials.php to read real quotes from published authors. 